\title{
LA PRESUNCIÓN DE ATEÍSMO SEGÚN ZUBIRI*
}

\author{
ENZO SOLARI \\ Pontificia Universidad Católica de Valparaíso
}

\begin{abstract}
RESUMEN: Este trabajo muestra cómo es que Zubiri discutió a lo largo de su extensa obra -incorporando textos y cursos suyos recientemente editados - que exista una presunción intelectual en favor del ateísmo y en cambio sugirió que este está en idéntica posición intelectiva que el teísmo y el agnosticismo, para lo cual se reconstruyen en la filosofía madura de Zubiri sus análisis tanto del logos ateo como de la razón del ateísmo y se añaden finalmente algunas perspectivas especialmente práctico-políticas de prolongar esta filosofía del ateísmo.
\end{abstract}

PALABRAS CLAVE: ateísmo; filosofía de la religión; fenomenología; logos; razón.

\section{The presumption of atheism according Zubiri}

ABSTRACT: This paper shows how the whole of Zubiri's work -incorporating his recently edited texts and courses - argued against a favorable presumption of atheism, and instead suggested that atheism remains in identic intellectual status that theism and agnosticism. In order to do this, the paper rebuilds in Zubiri's mature philosophy, his analyses about an atheistic logos and a reason of atheism, and at the end it adds some practical and political perspectives in order to explain this philosophy of atheism.

KEY WORDS: atheism; philosophy of religión; phenomenology; logos; reason.

El ateísmo ha ganado cuerpo intelectual en los últimos siglos, especialmente dentro de la tradición occidental, a veces con precauciones y matices que lo aproximan a alguna variante del agnosticismo, a veces de modos más explícitos, sistemáticos, aun polémicos. Y si bien hay tradiciones ateas fuera de Occidente, así como otras occidentales muy anteriores a la modernidad, es en el Occidente moderno que el ateísmo exhibe algo peculiar que empieza a desarrollarse desde la Ilustración radical en adelante ${ }^{1}$.

Darwin, por poner un ejemplo, creía detestable (damnable) la doctrina según la cual los no creyentes «recibirán un castigo eterno» o que el Antiguo Testamento, «debido a su versión manifiestamente falsa de la historia del mundo

* Este texto se ha beneficiado del financiamiento otorgado por una beca C de Stipendienwerk Lateinamerika-Deutschland (Consejo Valparaíso, Chile): El ateísmo en el curso El problema de Dios de Xavier Zubiri.

1 Se diría incluso que en la actualidad el ateísmo militante de Dawkins, Hitchens y otros no es más que un revival del de los ilustrados radicales, como Jean Meslier, el coadjutor francés que influyera en Diderot y D’Holbach, quien escribió en su Testamento: «que todo lo que está ocurriendo en el mundo en relación con el culto y la adoración de los dioses no es sino un error, un abuso, una ilusión, mendacidad y traición; que todas las leyes y ordenanzas publicadas bajo la autoridad de Dios o de los dioses solo son invenciones humanas, igual que todos los hermosos espectáculos y fiestas y sacrificios y todas las demás prácticas y devociones en su honor»: Meslier, J., Oeuvres complètes Vol. 1: Testament, ed. R. Desné, Anthropos, París 1970, p. 27, citado por Blom, Ph., Gente peligrosa. El radicalismo olvidado de la Ilustración europea, trad. D. Najmías, Anagrama, Barcelona, 2012, p. 133. 
[...], no era más de fiar que los libros sagrados de los hindúes o las creencias de cualquier bárbaro», agregando además que el sufrimiento de millones de seres animales obligaría a admitir una idea repugnante: «que su benevolencia no es ilimitada (that his benevolence is not unbounded) »². Argumentos más sutiles, como el antiguo del diseño en la naturaleza (design in nature) revitalizado por Paley, "falla tras el descubrimiento de la ley de la selección natural (fails, now that the law of natural selection has been discovered)» ${ }^{3}$. Sin embargo, Darwin pensaba que su actitud tenía alguna analogía con la del daltónico, aunque a condición de no olvidar que la creencia en la existencia del color rojo es universal, mientras que la creencia en un solo Dios personal no lo es ${ }^{4}$. Decía merecer el calificativo de "teísta», entendiendo por tal a aquel que busca «una Primera Causa que posea una mente inteligente análoga en algún grado a la de las personas», si bien tal conclusión, que veía como sólida en la época en que escribiera El origen de las especies, «se ha ido debilitando gradualmente, con muchas fluctuaciones (it has very gradually with many fluctuations become weaker)», aceptando de paso que la creencia en Dios puede deber su fortaleza psicológica y aun social a su carácter de "experiencia heredada», a su temprana introducción en la mente de los niños ${ }^{5}$. Las implicancias de ese debilitamiento y de estas fluctuaciones no son del todo claras. Sea de ello lo que fuere, Darwin se confiesa agnóstico: «no pretendo proyectar la menor luz sobre problemas tan abstrusos», y por lo mismo reconoce que «nada hay más importante que la difusión del escepticismo o el racionalismo durante la segunda mitad de mi vida (nothing is more remarkable than the spread of scepticism or rationalism during the latter half of my life) ${ }^{6}$.

Einstein es otra prueba al respecto, más severa si cabe. En una carta del 3 de enero de 1954 dirigida al filósofo Eric Gutkind, dijo que «la palabra Dios no es para mí más que expresión y producto de las debilidades humanas (menschlicher Schwächen)», que la Biblia colecciona en el fondo leyendas primitivas, que toda religión es la «encarnación de una superstición primitiva (des primitiven Aberglaubens)». Incluso le enrostra a Gutkind que como ser humano acepte una suerte de dispensa para la causalidad y que como judío suscriba un privilegio para el monoteísmo, sin parar mientes en que «una causalidad limitada (eine begrenzte Kausalität) [...] no es causalidad alguna (ist überhaupt keine Kausalität mehr)», como ya se dio cuenta «nuestro magnífico Spinoza

2 Darwin, Ch., Autobiografía, trad. J. L. Gil, Laetoli, Pamplona, 2008, pp. 78, 77 y 80 , respectivamente.

3 Ibid., p. 78. Y agrega: «ya no podemos sostener, por ejemplo, que el hermoso gozne de una concha bivalva deba haber sido producido por un ser inteligente, como la bisagra de una puerta por un ser humano»: DARWIN, Autobiografía, p. 78. Por cierto, filósofos recientes han retomado la crítica darwiniana al argumento del diseño; por todos, véase DennetT, D., Romper el hechizo. La religión como fenómeno natural, trad. F. De Brigard, Katz, B. Aires, 2007, pp. 287-288.

4 DARWIN, Autobiografía, p. 81.

5 Ibid., p. 82.

6 Ibid., pp. 83-84. 
(unser wunderbarer Spinoza)», y en que la comprensión animista de las religiones naturales (die animistische Auffassung der Naturreligionen) no es superada en principio a través de la monopolización (monoteísta) ${ }^{7}$.

Este tipo de reflexión ha conducido al argumento que, subrayando debilidades (científicas y aun morales) en las afirmaciones y razones teístas, alega una suerte de presunción de ateísmo, esto es, de un mayor peso racional en su favor que de ser contestable obligaría al contestador a una específica e intensa argumentación contraria. Pues bien, quisiera sugerir que esta configuración del argumento ateo precisa de un examen filosófico. Y de uno hecho con rigor, sine ira et studio. El asunto tiene interés, y por lo mismo no es novedoso sino que ha sido abordado desde hace tiempo ${ }^{8}$. Aquí me propongo exponer y enjuiciar el

7 El texto de esta carta recientemente subastada se halla en https://www.youtube.com/ watch? $\mathrm{v}=\mathrm{C} 2 \mathrm{~s} 3$ exvrjbE\&noredirect $=1$.

8 Por ejemplo, sobre la imposibilidad de una presunción favorable al ateísmo, Kant mismo ya estableció algunas cosas insoslayables. En la Metaphysik-Dohna-Wundlacken de 1792-1793, sobre la base de la Metaphysica de A. G. BAumgarten $\left({ }^{1} 1739,{ }^{4} 1757\right)$ : si deísta es el que admite la teología trascendental (para la que Dios es ens summum), y teísta el que admite la teología física (para la que Dios es summa intelligentia, primer motor —objeto de demostración mecánica- y además el que «ha dado formas conforme a fines» —objeto de demostración teleológica-), el ateo es "el que niega un ente originario»: Kant, I., MetafísicaDohna, trad. M. Caimi, Salamanca, Sígueme, 2006, pp. 104-105 (Ak. XXVIII.2.1.: 691). Pero, Kant tiene que distinguir: el ateo puede ser escéptico o dogmático. Escéptico es el «ateísmo de la duda». Dogmático es el de la «negación de Dios». Este es el «atheismus crassior -el que niega por completo a un ente originario como inteligencia; subtilior -el que junto al ente originario inteligente concibe también a la materia como ente originario»: ibid., p. 105 (Ak. XXVIII.2.1.: 691). Esta distinción kantiana de dos ateísmos, o más bien —se diría— de agnosticismo - ateísmo escéptico o de la duda - y ateísmo propiamente tal —ateísmo dogmático o de la negación de Dios-, se desarrolla más y mejor en la argumentación de las Vorlesungen über die philosophische Religionslehre de 1783-1784, elaboradas sobre la base de la Metaphysica de A. G. Baumgarten (parte IV, parágrafos 800-1000) y de la Preparación para la teología natural de J. A. EBerhard (1781). El ateo dogmático, dice Kant, «niega absolutamente la posibilidad de un Dios y afirma que Dios no existe. Negar la existencia de un ens realissimum y la posibilidad del mismo es aquí en rigor, donde tratamos con la razón pura, una y la misma cosa»: Kant, I., Lecciones sobre filosofía de la religión, trad. A. del Río y E. Romerales, Akal, Madrid, 2000, p. 91 (Ak. XXVIII.2.2.: 1023). Por lo mismo, "cuando el ateo dogmático niega que Dios existe, se impone con ello a sí mismo la obligación de probar que es imposible que haya Dios»: ibid., p. 91 (Ak. XXVIII.2.2.: 1023-1024). Para hacerlo, debe demostrar conceptualmente que algo — aquí Dios - no existe porque se contradice a sí mismo: «el ateo dogmático tendrá, por tanto, que probar previamente que el objeto que corresponde a nuestra idea de un ens realissimum se contradice a sí mismo en la unión de sus predicados y que, en consecuencia, es imposible, antes de poder arrogarse el derecho de querer afirmar que una cosa tal no existe»: ibid., p. 91 (Ak. XXVIII.2.2.: 1024). Lo mismo vale, dice Kant, para el que pretende demostrar a priori que Dios existe: debe probar con certeza apodíctica que Dios es posible, es decir, que sus predicados se unen, que «la síntesis de todos sus predicados no se contradice a sí mismo»: ibid., p. 91 (Ak. XXVIII.2.2.: 1024). Y según Kant, tanto esto como aquello — demostrar la imposibilidad o la posibilidad del objeto de mi idea-constituyen imposibles tareas para la razón humana. En efecto, no es posible «poder probar a priori por mi razón de manera apodícticamente cierta que las perfecciones están reunidas en un tronco y que pueden ser derivadas de un principio [...] Tengo que reconocer [...] mi incapacidad para 
examen del argumento por parte de Xavier Zubiri, alguien que ha explorado tal presunción atea del modo en que ha de hacerse, esto es, detalladamente y sin patetismo alguno: «la filosofía no tiene más patetismo que la monotonía de la verdad escueta», decía en $1965^{\circ}$.

Esta es una tarea que, a mi modo de ver, tiene cuando menos tres justificaciones. Primera, que las presentaciones del ateísmo en la filosofía de Zubiri, incluso las recientes, suelen limitarse a reproducir las palabras del filósofo vasco al respecto, sin darse el trabajo de reconstruir su argumentación a la luz de su entera filosofía ${ }^{10}$. De ahí que ofrezca en lo que sigue reconstruir con pretensiones sistemáticas el argumento de Zubiri respecto del carácter del ateísmo tal como dicho argumento florece al interior de su filosofía general y de la religión

inteligir la posibilidad de una síntesis de todas las realidades posibles con respecto a todos sus efectos»: ibid., p. 92 (Ak. XXVIII.2.2.: 1025). Y en cuanto al ateísmo, agrega Kant, tampoco es posible la prueba de la imposibilidad divina: «también es imposible para toda razón humana probar alguna vez que una composición tal de todas las perfecciones en una única cosa sea imposible; pues para ello haría falta a su vez una intelección de la extensión de todos los efectos de la totalidad íntegra de la realidad, siendo las mismas razones, por las que es patente la incapacidad de la razón humana para afirmar la existencia de un ser tal, por necesidad también suficientes para probar la invalidez de toda afirmación contraria». En resumen, dice Kant en las Lecciones, «que es imposible probar que Dios es imposible. Por el contrario: la razón no me pone el menor obstáculo para admitir la posibilidad de Dios, si de alguna otra manera me siento obligado a ello»: ibid., p. 92 (Ak. XXVIII.2.2.: 1026). Y dado que la facultad racional humana tiene límites irremontables, «es así como se viene abajo el edificio del ateo dogmático»: ibid., p. 93 (Ak. XXVIII.2.2.: 1026). Al tener que demostrar la imposibilidad de Dios, «su razón le abandona, y todo lo que él alega en contra es absurdo y carece de sentido», pues ni la posibilidad ni la imposibilidad de Dios pueden ser probadas a priori, lo que deja abierto — sin el menor obstáculo, agrega Kant— el camino «para admitir la posibilidad de Dios, si encontráramos de alguna otra manera razones convincentes para ello»: ibid., p. 93 (Ak. XXVIII.2.2.: 1026). Ahora bien, como se sabe, el teísmo kantiano es moral, lo que permite deducir una suerte de presunción moral favorable al teísmo. Para Kant, en efecto, aun sin una prueba de la existencia de Dios, puede refutarse al ateo dogmático. Y lo mismo cabe hacer con el ateo escéptico. Al que duda, con perfecto derecho, de la capacidad humana de probar especulativamente la existencia del ser sumamente perfecto, habría que argumentarle que, «aun concediendo la insuficiencia de todas las pruebas especulativas de la existencia de Dios en cuanto ens realissimum, nos sentimos no obstante convencidos en lo más hondo, por razones prácticas, de que tiene que haber un Dios. Tenemos que admitir un Dios y creer en él, sin que le esté permitido a la razón atreverse a admitir a priori su posibilidad y su existencia»: ibid., p. 93 (Ak. XXVIII.2.2.: 1026-1027).

9 Zubiri, X., Sobre la religión, Alianza Editorial, Madrid, 2017, p. 14.

10 Véase por ej. Gudiel, H., La fe según Xavier Zubiri. Una aproximación al tema desde la perspectiva del problema teologal del hombre, Editorial de la Pontificia Universidad Gregoriana, Roma, 2006, pp. 160-166, que es en lo sustancial cita de Naturaleza, Historia, Dios y El hombre y Dios, o —-más cerca de la tesis que aquí defenderé- GARcía, J. J., «Legitimidad de las opciones no teístas en la filosofía de Xavier Zubiri», en The Xavier Zubiri Review 11 (2009), pp. 47-54, que sigue casi siempre El hombre y Dios, con alguna remisión a la trilogía sobre la inteligencia. Acerca de la necesidad de reconstrucción sistemática y a la vez atenta a los diferentes usos que "ateísmo" puede tener en la evolución de Zubiri, véase PinTor-Ramos, A., «Desarrollo del concepto de religación en Zubiri», en Cuadernos salmantinos de filosofía, 42, 2015, pp. 85-129, aquí pp. 95-96. 
—especialmente junto a las actitudes concurrentes: el agnosticismo, el teísmo, el indiferentismo. En segundo lugar, es necesario ampliar la base textual de trabajo, incorporando los textos zubirianos que se han sucedido después del año 2006 (fecha en la que yo mismo terminé de elaborar una interpretación sistemática de la filosofía de la religión según Zubiri —y, muy sucintamente, del lugar que el ateísmo ocupa en su interior). Como algunos de estos textos son inéditos, deberé examinar si contienen novedades para la cuestión del ateísmo. Otros textos de Zubiri, no inéditos pero sí vueltos a editar con modificaciones, deben ser releídos cuidadosamente, ya que, aunque editados con anterioridad, lo habían sido de maneras críticamente poco fiables, en la medida en que el editor de turno fundía textos de orígenes distintos, separaba otros de fuente común, y en gral. intervenía sin seguir las prácticas usuales de la crítica textual. Pero la tercera, y principal, justificación de este artículo es la sgte.: que tal visión zubiriana del ateísmo tiene su interés desde el punto de vista de la actual filosofía de la religión, y esto por las novedades que introduce en los actuales debates sobre el ateísmo. Lo que obliga a elaborar filosóficamente tanto aquello que el ateísmo tiene en común con el teísmo y el agnosticismo (y aun el indiferentismo), como aquello que tiene de específico.

\section{Ateísmo y ReLigación En 1975/1983}

En sus últimos años, Zubiri argumentó que el ateísmo es una actitud radical ante el problema de Dios - ese problema que todo ser humano no solo tiene sino que es-, y que como tal opción fundamental (dejando aparte ciertas sutiles formas de argumentación estrictamente racional) está situada en pie de igualdad con, y constituye una mentalidad tan razonable como las demás actitudes que ante dicho problema puedan tomarse: la teísta, la agnóstica, la indiferente. Así, ninguna opción ha de presumirse dejando a las demás en la necesidad de desbaratar a la mejor situada.

1.1. Lo que suele decirse del ateísmo en Zubiri se afinca en lo que este dejara escrito en la redacción definitiva de El hombre y Dios. En ese texto de 1983, Zubiri dice que teísmo y ateísmo «son actitudes ante una posible solución al problema de la búsqueda», y que tal problema teologal es previo: «la religación que lanza a la búsqueda es lo único primario. Lo demás, las actitudes, aun las verdaderas, son algo derivado» ${ }^{11}$. Todas las actitudes, aunque lo nieguen, viven afincadas en el mismo hecho radical, el cual plantea un problema universal: el problema de Dios, del cual surgen creencias diversas que tienen que justificarse $^{12}$. El ateísmo puede tener su origen —aunque esto no es siempre así- en

11 Zubiri, X., El hombre y Dios, Alianza Editorial, Madrid, ${ }^{22012}$, pp. 125 y 126; lo mismo en p. 123.

12 Ibid., pp. 21-22. 
una fatiga o astenia de lo absoluto, a la que siguen fenómenos bastante generalizados como la objetualización y el alejamiento vital de Dios ${ }^{13}$. En un sentido semejante, podría decirse que algunos ateos actuales son más bien teístas de un Dios ocioso ${ }^{14}$.

El ateísmo no es la actitud de despreocupación (o indiferencia) o de suspensión de juicio (o agnosticismo) respecto del problema de Dios, sino la actitud del que niega el problema o, en palabras de Zubiri, de aquel para el que jamás ha sido problema ${ }^{15}$. Sus problemas, los que tiene cualquier ser humano, son siempre y solo "problemas intra-vitales» ${ }^{16}$. La vida en su conjunto "es lo que es y nada más. Es la vida que reposa sobre sí misma» ${ }^{17}$. Por lo mismo, la «vida atea» no debe ser definida por contrariar la realidad divina, sino solamente por "el sentido meramente privativo del prefijo "a" ${ }^{18}$.

$\mathrm{El}$ ateo cree que «la conditio possidentis, que diría un jurista, sería el hecho de la vida a-tea. Lo demás son opciones y, recíprocamente, solo "lo demás" es opcional» ${ }^{19}$. Por supuesto, Zubiri no está de acuerdo con esto. Nadie deja de tener el problema de Dios. El poder de lo real en (y no fuera de) las cosas nos religa y provoca que cada acto sea la construcción de nuestro ser sustantivo ${ }^{20}$. Tal es «la fundamentalidad de mi vida [...] Es "el" hecho de la vida ${ }^{21}$. Ya hay un problema incluso antes de la cuestión «de si ese enigma está fundado en la realidad de Dios ${ }^{22}$. Ahora bien, el problema del poder y de la fundamentalidad nos lanza a inteligir qué sea aquel poder, aquella fundamentalidad: es justo el orto de un proceso intelectivo"23. Precisamente la intelección del poder de lo real como un hecho y solamente como un hecho sin fundamento es el ateísmo: «es la pura facticidad del poder de lo real $»^{24}$. Pero esta facticidad de la fundamentalidad no obsta a que la vida atea sea tan problemática como la vida teísta, agnóstica o indiferente. La facticidad no es puro hecho, sino una solución, una interpretación (con todas las razones del caso) del problema de Dios. Por eso hay que decir que tanto el teísmo como también el ateísmo «son dos modos como concluye el proceso intelectivo respecto del problema del poder de lo real $»^{25}$. Además, la facticidad es a la vez autosuficiencia de la vida, es la opción por la vida que se basta a sí misma. "Y por ser opción es entrega

13 Ibid., p. 181.

14 Ibid., pp. 274 y 277; un tratamiento más detallado se da en las pp. 293-298, y resúmenes en pp. 299-300 y 307.

15 Ibid., pp. 293-294.

16 Ibid., p. 294.

17 Ibid., p. 294.

18 Ibid., p. 294.

19 Ibid., p. 294.

$20 \quad$ Ibid., pp. 294-295.

21 Ibid., p. 295.

22 Ibid., p. 295.

23 Ibid., p. 295.

24 Ibid., p. 295.

25 Ibid., p. 296. 
personal a la facticidad, es fe en la facticidad. El ateísmo es justo la fe del ateo ${ }^{26}$. Si la fe es entrega de persona a persona, entonces «el ateo se entrega personalmente a su propia realidad formal como única y suficiente realidad personal verdadera $»^{27}$.

La voluntad de fundamentalidad, con sus momentos de opción e intelección, es característica de toda vida humana. En el ateo la voluntad de fundamentalidad «se despliega en intelección del poder de lo real como pura facticidad, y en opción por la autosuficiencia de la vida personal $\aleph^{28}$. La facticidad autosuficiente de la vida atea es «un modo de ser absoluto en su línea» ${ }^{29}$. Es la vida «que termina en sí misma», la vida cuyos actos determinadores del yo configuran su específica manera puramente fáctica y plenamente autosuficiente de ser relativamente absoluta. Para el ateo, «la voluntad de fundamentalidad es voluntad de ser relativamente absoluto» $\mathrm{o}$, en breve, voluntad de $\operatorname{ser}^{30}$.

1.2. Antes, en 1975, en el breve artículo de homenaje a Rahner «El problema teologal del hombre», Zubiri ya decía algo semejante:

«el hombre actual, pues, sea ateo o teísta, pretende que no tiene en su realidad vivida un problema de Dios. No piensa que su ateísmo o su teísmo sean respuestas a una cuestión previa, justamente a un problema que a sus creencias subyace. Recíprocamente, justo por ser solución a un problema, el teísmo tiene que justificar su creencia, pero el ateísmo está igualmente forzado a ello; el ateísmo no es menos creencia que el teísmo. Ni el teísmo ni el ateísmo están en situación de no necesitar fundamentar su actitud. Porque una cosa es la firmeza de un estado de creencia, y otra, su justificación intelectual. Y la raíz última de esta justificación intelectiva de lo que sea o no sea Dios se halla forzosamente en el descubrimiento del problema de Dios en el hombre. El hecho de este problema y no una teoría es lo que ha de constituir nuestro punto de partida ${ }^{31}$.

Por ello, el ateísmo se inscribe en el problema teologal del hombre y es una de las posibles actitudes ante el mismo ${ }^{32}$. Tales son no puras actitudes teóricas, sino experienciales: «el ateísmo, el teísmo, la agnosis son modos de experiencia del fundamento de lo real. [... Y] esta experiencia fundamental es individual, social e histórica» ${ }^{33}$.

Ibid., p. 297.

Ibid., p. 297.

Ibid., p. 297.

Ibid., p. 298.

Ibid., p. 298.

Ibid., p. 4; lo mismo en p. 10.

Ibid., p. 6.

Ibid., p. 12. 


\section{NUEVAS PISTAS SOBRE LA FORMACIÓN DEL ATEÍSMO EN ZUBIRI}

Ahora es posible considerar textos que se han publicado recientemente. En concreto, textos posteriores al 2006 y que tocan la cuestión de Dios. Por un lado, la nueva edición ya citada — con el texto de 1983 y el curso romano de 1973 - de El hombre y Dios, y, por el otro, la edición del curso inédito El problema teologal del hombre: Dios, religión, cristianismo de 1971 y de los tres cursos teologales de 1965-1968 ahora publicados en Sobre la religión. Pero hay más. También es necesario aprovechar algunas ideas de inéditos aún no publicados, como el curso «El problema de Dios» de 1948-194934. En general, estos cursos continúan y a la vez prolongan las reflexiones de «En torno al problema de Dios», de 1936, bajo la perspectiva de la filosofía que Zubiri va madurando desde los años 40 en adelante. Por eso aparece la religación (que no es obligación), la deidad y su fundamentalidad, la implantación (y no mero arrojamiento: Geworfenheit), el poder de la realidad y sus caracteres último, posibilitante e imponente o impelente, la voz de la conciencia, el yo como ser de la persona o personeidad, y esta personeidad (no la naturaleza humana) como aquello que formalmente está religado, el problema de Dios y su historia, las distintas actitudes y vivencias radicales que dicho problema desencadena, como las religiosas -y entre estas, las politeístas, las panteístas y las monoteístas- y las irreligiosas — como las indiferentes, las agnósticas y las ateas ${ }^{35}$.

2.1. En el curso «El problema de Dios» de 1948-1949, Zubiri sugiere que el problema de Dios se asienta en la religación a la deidad, pero también es tomado como el inexorable lanzamiento intelectivo desde esa deidad hacia una determinación (que puede ser en último término positiva, negativa o suspensiva) de su fundamento. La distinción entre la deidad y el problema de Dios es la distinción entre un enigmático ámbito siempre descubierto y la búsqueda abierta y diversa a la que ese ámbito empuja. La deidad no es problemática por sí misma, aunque sí que plantea un problema, el problema de Dios, justamente la búsqueda de una realidad última y absoluta. Tal búsqueda da origen a diversas actitudes y creencias frente al común problema de Dios planteado por la deidad que nos religa.

El ateísmo, en algún sentido relevante, puede ser entendido como negación tanto de la deidad como del problema de Dios. Para Zubiri, hay variadas formas de ser ateo: la irreligión que se aprecia en la India con el Sankia (y su influjo en el saidismo y el budismo), el zurbanismo iraní (en la religión de Zoroastro), el ateísmo israelita (a cuya tesis - Yahvé no es el Dios de Israel- arriba por impiedad, o por falta de confianza, o por negar la absolutidad y exclusividad de Yahvé), en Grecia el ateísmo respectivo a los dioses de las $\pi$ ó $\varepsilon ı \varsigma$ (según el cual

34 Al que he tenido acceso por autorización de la Fundación Xavier Zubiri de Madrid.

35 Véanse resúmenes de algunas de estas tesis: ZuBIRI, Religión, pp. 57-59, El problema teologal del hombre: Dios, religión, cristianismo, Alianza Editorial, Madrid, 2015, pp. 317-319, 423-425, 515-516, etc. 
se recusa la existencia de dioses, o se afirma o su despreocupación por los hombres o su excesiva preocupación por ellos y su consiguiente manipulabilidad a través de la oración y los sacrificios) ${ }^{36}$, los ateísmos europeos (¿el panteísmo naturista de G. Bruno y de B. Spinoza?, ¿el deísmo de Voltaire?, ¿el idealismo de Hegel?, ¿el positivismo cientista que lleva al agnosticismo?, en todo caso Nietzsche y el endiosamiento existencialista de la vida).

El ateo, piensa Zubiri, también tiene un problema de Dios. Claro que la suya es otra respuesta a la misma pregunta, pues es una creencia que niega toda realidad última y absoluta. Zubiri parece incurrir en contradicción: afirma aún que el ateísmo es una existencia desligada (según decía peyorativamente en «En torno al problema de Dios» durante los años 30 y aun 40), pero añade que solo es comprensible sobre la base de la deidad que religa la existencia (inconsistencia que en todo caso supone un avance respecto de aquel texto y añade un matiz menos peyorativo sobre la actitud atea). «A su modo, naturalmente, el hombre es divino", dice Zubiri, y esto tanto por la deidad como por el problema de Dios. Zubiri cita a Nietzsche cuando dice: «si existiera un Dios, ¿cómo podría soportar yo no serlo?». El sentido profundo de esa frase es que el hombre es humano y divino, ni demasiado humano ni demasiado divino, un pequeño Dios: esto, según Zubiri, es lo que hay de verdad en el ateísmo ${ }^{37}$.

2.2. En «El problema filosófico de la historia de las religiones» de 1965 (Madrid), Zubiri mantiene la noción de «deidad» como distinta de la de «Dios» (en una nota al margen dice: «no todas las religiones tienen dioses $»^{38}$ ). Y dice, más novedosamente, que la deidad es una condición de la realidad de las cosas precisamente en tanto que y porque ellas vehiculan un poder: "un poder real y efectivo, fundamental, último, posibilitante e imponente, que no es ciertamente una realidad distinta del mundo» ${ }^{39}$. Por este poder de las cosas es que, rigurosamente hablando, se vive una experiencia o actitud radical: «en todo acto

36 Nótese que años antes, en lecciones privadas datables entre 1941 y 1943, Zubiri decía que «los griegos nunca han dudado de la existencia de los dioses. Aristóteles habla, es verdad, de un peligroso ateísmo, $\dot{\alpha} \theta \varepsilon o ́ \tau \eta\rceil \alpha$, pero se refiere a los que niegan el carácter divino del cosmos y no a lo que nosotros llamaríamos ateísmo": ZuBIRI Introducción a la filosofía de los griegos, Alianza Editorial, Madrid 2018, p. 179. Es cita del fragmento 18 según las ediciones de Rose y Ross (Filón, Sobre la eternidad del mundo 3, 10-11): «Aristóteles [...]

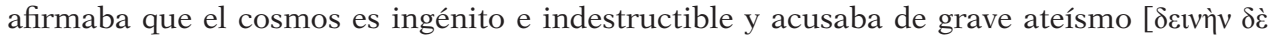
$\left.\left.\dot{\alpha} \theta \varepsilon \varepsilon^{\tau}\right\rceil \tau \alpha\right]$ a quienes sostenían lo contrario, porque creyeron que no hay ninguna diferencia entre las cosas fabricadas a mano y este dios visible, que contiene el Sol, la Luna y el resto de los planetas y las estrellas fijas, como un verdadero panteón [...]»: ARISTóteles, Sobre la filosofía, en Fragmentos, trad. A. Vallejo, Gredos, Madrid, 2005, pp. 257-322, aquí p. 296 (W.

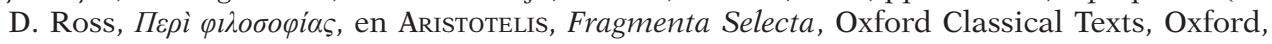
1955, pp. 73-96, aquí p. 85).

${ }_{37}$ Véase el texto que se conserva en Madrid de este curso, pp. 613-9/655-51, y SolARI, E., La raíz de lo sagrado. Contribuciones de Zubiri a la filosofía de la religión, RIL editores, Santiago de Chile, 2010, pp. 152-153.

38 ZuBIRI, Religión, p. 52 n. 28.

$39 \quad$ Ibid., p. 45; véanse pp. 39-45. 
personal, aun en el más modesto, subyace precisamente esta vivencia oscura, larvada, incógnita, generalmente muerta en el anonimato, pero real, que es la experiencia de la deidad» ${ }^{40}$.

En el ateo se presenta la misma experiencia o actitud, sea en el ateísmo «profesado en cuanto tal», sea en la indiferencia o agnosticismo: «yo no soy ateo, ni creo ni dejo de creer. Yo me contento con la facticidad del vivir» ${ }^{41}$. Aquí como allí se constata la misma religación, idéntica deidad, solo que modulada de diferentes maneras. Es el enigma, el misterio sagrado de la deidad, presente por igual en budistas y místicos cristianos ${ }^{42}$. Por lo mismo, no hay que confundir la religación con otras dimensiones humanas, como la de la moralidad hecha de obligaciones y deberes. El punto en el que se encuentra la religación con una obligación es la conciencia humana. Mas, hay que distinguir. La ligazón del hombre a su conciencia "no es una obligación moral; es una religación»" Más allá de lo que la voz de la conciencia le dicte al hombre que debe hacer, este oye y no puede menos que oír esa voz: es el hecho de que una voz categóricamente imperativa resuena en él. Zubiri cree que se puede hablar aquí de moral religiosa, algo toto caelo distinto de una moral de los deberes, pues la moral religiosa consiste en el «acatamiento de aquello que imponentemente nos impulsa o nos da la deidad», y la infracción a ese acatamiento no es mera falta moral, sino peccatum contra la deidad ${ }^{44}$.

Más allá de estas cuestiones, Zubiri, incluso hablando desde un punto de vista teológico (y apoyándose en Rahner), comenta que en las religiones hay no solo tesoros y conformidades con la verdad cristiana, sino también deformidades - aunque añadiendo que solo algunas de tales depravaciones quizá se ubiquen al interior del núcleo esencial de cada religión, mientras que otras seguramente están en efecto fuera de ese núcleo esencial. Y pese a ello, las religiones — «toda religión», dice- son legítimas, pues en ellas puede admitirse que hay algo de conformidad, algo querido divinamente con una suerte de beneplácito de permisión ${ }^{45}$. Lo que podría decirse analógicamente de las actitudes ateístas y agnósticas, o sea, que, visto teológicamente, en ellas hay o puede haber algo de conformidad y algo de deformidad.

2.3. En el curso «El problema de Dios en la historia de las religiones» de 1965 (Barcelona), Zubiri repite que la deidad o religación es un hecho inconcuso, por más que no se la reconozca temática y explícitamente: "podrá un ateo no emplear la palabra "deidad"; me importaría exactamente lo mismo. Porque lo que estamos describiendo no es una teoría de Dios ni una fundamentación; es pura y simplemente la constatación (el hecho inconcuso) de que en el

\footnotetext{
$40 \quad$ Ibid., p. 46.

$41 \quad$ Ibid., p. 46.

$42 \quad$ Ibid., pp. 51-52.

43 Ibid., p. 47.

44 Ibid., p. 49.

45 Ibid., pp. 264-266.
} 
hombre acontece efectivamente, en esta forma de poder, el poder de la realidad, la deidad $»^{46}$.

Allende esto, Zubiri añade teológicamente (de nuevo aludiendo a Rahner) que en otras religiones (sin decirlo, cabría añadir que también en otras actitudes fundamentales irreligiosas) puede encontrarse salvación y gracia. Y no solo si y porque aquel creyente (el budista, por ej., dice Zubiri) está de buena fe, sino también por su misma actitud fundamental, y sin que ello suponga admitir que todo en una creencia sea conforme: «no se puede identificar, naturalmente, el que una religión tenga gracias para salvar a los hombres, con el hecho de que en esa religión todo sea querido por Dios ${ }^{47}$. Zubiri recuerda la idea de que en Dios hay una voluntad de beneplácito y de permisión, incluso una de beneplácito precisamente de la permisión ${ }^{48}$.

2.4. En el curso «El hombre y el problema de Dios» de 1968 (Madrid) hay otras tantas pistas. En la primera sesión, Zubiri asegura que, radicalmente entendido, el ateísmo considera a «Dios» como concepto carente de sentido. Sus formas, añade, son el ateísmo vital (para el cual no hace falta Dios para vivir, lo que no es una negación de Dios, sino del problema de Dios como problema: un no-teísmo), el ateísmo político-social (que ya es verdadero ateísmo, negación expresa de Dios, como en el marxismo) y el ateísmo religioso (para el que no es que no haya Dios, sino que su existencia es indiferente para la vida humana: lo que importa es no Dios sino Cristo, y Cristo no como Dios sino como hombre: así Barth, Bultmann, Tillich y Hamilton). Estas tres formas de ateísmo actual tienen algo en común, y por ello son superiores a los ateísmos de otras épocas: el hombre está vertido al problema de Dios, y por otro lado, esta versión problemática no aleja de, sino que conduce a, la realidad humana en tanto que humana ${ }^{49}$.

Hay también aquí una interesante aclaración del sentido no moral de «voz de la conciencia». Para Zubiri, conciencia no significa en este contexto conciencia moral ni deber, ni «cum-scientia» o «darse-cuenta-de», sino aquello que «modula la inscripción de toda actitud y de todo acto en ese acto emergente, que es el despertar del Yo, es decir, del ser sustantivo ${ }^{50}$. La voz de la conciencia es una voz judicativa, que juzga, mas el juicio que emite no es necesariamente uno de deber, como tampoco es necesario que sea «un juicio de adecuación entre un acto que está ejecutado y aquello que en una u otra forma, uno quisiera, o por lo menos pretendería que formara parte de su ser sustantivo ${ }^{51}$. Lo que sí ha de decirse en cambio, según Zubiri, es que este juicio de la voz

\footnotetext{
$46 \quad$ Ibid., p. 320.

47 Ibid., p. 369.

$48 \quad$ Ibid., pp. 369-371.

49 Ibid., pp. 382-390; véanse pp. 415-416.

$50 \quad$ Ibid., p. 427.

$51 \quad$ Ibid., p. 428.
} 
de la conciencia juzga precisamente el «alcance que va a tener el acto que voy a ejecutar ${ }^{52}$. Sea lo que fuere aquello que voy a hacer, la voz de la conciencia me dicta el alcance de lo que haré, "y ese alcance consiste en la configuración del ser, de mi ser sustantivo ${ }^{53}$. El acto a ejecutar puede incluso ser indiferente (ádiócopov), lo que no obsta a que la voz de la conciencia me hable: «en esta voz se expresa la inquietud radical en que el Yo, religado al poder de lo real, va haciendo su ser sustantivo, y que en esta forma de "voz de la conciencia" va modulando las actitudes que toma, y los actos que va ejecutando» ${ }^{54}$.

2.5. En el curso de 1971 sobre el problema teologal del ser humano, Zubiri asevera que el ser humano actual es ateo, pero no con un "ateísmo-contra», sino con uno que consiste en estar serenamente asentado y aposentado en la propia vida, una vida que se vive en sí misma y sin nada más ${ }^{55}$. De todos modos, el ateísmo es una opción, justo «la de asentarse positivamente en su vida, cosa que es tan poco evidente como el asentarla en un Dios uno y trino» ${ }^{56}$. Y es una opción ante el problema de Dios, «no en tanto que Dios, sino en tanto que problema del poder de lo real, el cual, sin embargo, es idéntico con el problema de Dios ${ }^{57}$. El ateo podrá no vivir el problema de Dios formaliter, «pero en sí, in re, materialmente, ¿no está poniendo en juego el poder de lo real, aunque no lo quiera llamar Dios?» ${ }^{58}$. Por eso Zubiri puede decir que «la religación es una dimensión esencial y constitutivamente personal del hombre, aun del hombre más ateo» ${ }^{59}$.

2.6. Importante es también el curso «El problema teologal del hombre: el hombre y Dios» de 1973 (Roma), según el cual el ateísmo sería

«la vida y el ser del hombre como pura facticidad [...] El ateísmo insiste sobre la facticidad: el hombre es así como es y no hay que darle más vueltas. Todo lo demás es un añadido que además el ateo estima que no puede llevarse a cabo. Ahora bien, el ateísmo, que es la pura facticidad del ser, consiste en

$52 \quad$ Ibid., p. 428.

53 Ibid., p. 428.

54 Ibid., p. 428.

55 ZuBiri, Problema teologal, pp. 3-4.

56 Ibid., p. 119; la idea reaparece más adelante en el mismo curso: «en todo caso, el que no tiene religión vive al menos de una opción de la fe: la de asentar la vida sobre sí mismo. Porque el no tenerla no es precisamente un estado natural, es una opción. Tan opción como el creer en Dos uno y trino [...] Es una opción real y positiva como puede ser el ser budista, católico o musulmán. La plasmación, pues, significa, por lo pronto, un acto personal que efectivamente prolonga, de una manera más o menos inexorable [...], esto que llamamos la religación» (p. 205).

57 Ibid., p. 95.

$58 \quad$ Ibid., p. 95.

59 Ibid., p. 722. Nótense estas curiosas frases: si históricamente ha sido más fácil ser ateo «por razones de naturaleza y de física que por razones de humanidad» (p. 105), hoy por el contrario lo es «por razones políticas» (p. 106), y que "para unos, Cristo en su historia, Dios en su historia, ha muerto: fue la frase de Nietzsche» (p. 781). 
interpretar el ser relativamente absoluto con un coeficiente de relatividad que consiste en afirmar su pura factualidad. El hombre es así en absoluto, y lo son cada uno de los hombres. Y nada más. [Pero] no. No es una conditio possidentis. No parece sino que la prueba incumbe únicamente al que no quiere ser ateo. No. El ateísmo necesita dar sus razones, porque de evidente no tiene nada. A esta actitud del ateo corresponde un proceso intelectivo que termina en la pura facticidad del ser y un modo de apropiación peculiar: el que cree que su ser relativo no es más que la facticidad de aquello que se es y tiene una actitud de apropiación para la vida que consiste en la autosuficiencia. El ateo se encuentra con una vida autosuficiente, precisamente en la medida en que aquello a que aboca su voluntad de búsqueda es el ser como pura facticidad [...] Es la no-fundamentalidad de la vida» ${ }^{60}$.

Parejamente:

«Uno piensa que está el hombre sin Dios, y entonces el que lo admite, que lo pruebe. Esto no es verdad. La verdad es que el hombre está religado al poder de lo real, que es en todos los hombres. El que va a Dios admite <dando razones> la existencia de Dios. Y el que no va tiene que probar que no va, tiene que dar razones. Lo primario no es estar sin Dios, sino estar religado al poder de lo real. Tanto el ateísmo como el teísmo son conclusiones de un proceso intelectivo y vital, dentro de esa religación, frente a la ultimidad de lo real» ${ }^{61}$.

\section{Fenomenología y Metafísica del PROBlema de Dios}

Pues bien: para presentar sistemáticamente lo que sea el ateísmo a la luz de la filosofía más madura de Zubiri, es necesaria una previa aclaración metodológica. En su filosofía de la religión, como en el resto de su producción filosófica, Zubiri distingue: una cosa es la religión y la irreligión, otra el análisis filosófico de ambas, y aún otra las teorías o explicaciones que se construyen a partir de las mismas. Sobre todo, no deben confundirse los fenómenos (religiones, ateísmos y agnosticismos) con lo que filosóficamente se diga de ellos, bien de modo analítico, bien de manera explicativa. Por más que en aquellos fenómenos se entreveren análisis y teorías que han llegado a formar parte del objeto de estudio, cuando se adopta la actitud filosófica ha de distinguirse entre tales autocomprensiones de la religión (y la irreligión) y el estudio filosófico de las mismas. Por otra parte, Zubiri piensa que la filosofía debe ser ante todo una fenomenología (una "noología», en sus términos), esto es, una descripción que no se solidarice con explicaciones y teorías metafísicas, sino que las anteceda y en cierta forma prepare. Así, el fenomenólogo puede estudiar los fenómenos

60 ZuBIRI, Hombre y Dios, pp. 440-441; la misma idea en p. 563, aunque añadiendo que el ateísmo es esa facticidad de lo absoluto que no descubre sino que encubre la experiencia de Dios: «ateamente, en este caso, el hombre está en Dios»; cita su texto de 1936 en pp. 563-564.

61 Ibid., p. 562. 
religiosos sin requerir ningún compromiso religioso particular, tal como puede estudiar los fenómenos del ateísmo y el agnosticismo sin estar comprometido tampoco con ellos. La epokhé fenomenológica desactiva las convicciones del filósofo de tal manera que ni la religiosidad del analista obstaculice el tratamiento de fenómenos irreligiosos, ni la irreligiosidad del mismo obste a la investigación de los religiosos. Solo así es practicable, cree Zubiri, una filosofía primera de la religión y la irreligión que intente realizar descripciones comunicables de hechos accesibles en principio para cualquiera ${ }^{62}$. En tal análisis consiste la aportación fundamental de Zubiri al estudio del ateísmo. Lo que no obsta a que Zubiri practique también metafísica de la religión - y de la irreligión-, ciñendo en este terreno perfilados argumentos sobre el concepto de Dios y acerca de la existencia del Dios concebible (uno en la vía de la religación y de la realidad, otro cosmológico, otro más de carácter antropológico, más otro fundado en el problema del mal), aunque nunca tan detallados como los fenomenológicos ${ }^{63}$.

3.1. El hombre, asegura Zubiri, es un animal que siente e intelige en cada uno de sus actos, tanto en los nimios cuanto en los más complejos y sofisticados. Lo que significa que todas las cosas quedan para él como realidades, como formalmente otras, dotadas de una alteridad radical. Esta realidad que el ser humano capta lo embarga y domina, tiene —en palabras de Zubiri— «fuerza de imposición». Y la tiene no por las propiedades concretas que poseen las cosas, sino por su carácter — su formalidad, dice Zubiri- de realidad. Lo que se nos impone a través de las cosas que se nos presentan en los actos es la fuerza misma de lo real. La realidad, dice Zubiri, es «más» que las cosas que la vehiculan - aunque nada sea fuera de las cosas. Y la realidad que no es solo tal o cual sino que es transcendental, simpliciter, se manifiesta en el ser humano «en tanto que realidad», pues este actúa a cada momento desde, por y en su propia realidad y desde, por y en la realidad de todas las cosas. El hombre se hace cargo de la realidad, tanto la que él es como la de las demás cosas. Por esta formal presencia de la realidad en su vida es que el hombre es persona. Y persona, para Zubiri, es la realidad que posee su propia realidad en cuanto realidad y que se enfrenta con la realidad en tanto que realidad.

3.2. Pero que el hombre sea persona implica algo más: que es una realidad fundada en la realidad. La realidad es más que cada cosa, es una fuerza. Como fuerza, se impone y domina al hombre. Se apodera de él: es un poder. Este poder dominante de la realidad hace de la realidad un fundamento. Es la

\footnotetext{
62 Solari, La raíz de lo sagrado, p. 369.

63 Este tratamiento metafísico, si bien es secundario en relación con el meramente analítico, nunca desaparece de la obra de Zubiri; un ejemplo, entre los textos publicados por primera vez tras el 2006, es Acerca del mundo, Alianza Editorial, Madrid, 2010, curso impartido en 1960, donde Zubiri argumenta la necesaria existencia de Dios como la realidad última y fundamental del mundo (pp. 203-243). Para una reconstrucción de estos argumentos, véase SOLARI, La raíz de lo sagrado, pp. 418-474.
} 
realidad precisamente como fundamento. $\mathrm{O}$, en los términos zubirianos, es la fundamentalidad de la realidad. La realidad es, para el hombre, un fundamento último, posibilitante e impelente. El hombre está apoyado para ser real en el poder de la realidad (es - en palabras de Zubiri- una vis a tergo). La persona humana, en este sentido, no puede por sí sola ser real, sino que la realidad es la que "puede» a la persona del hombre. Es lo que Zubiri trata de enfatizar cuando dice que el hombre vive «en» la realidad, «desde» la realidad y «por» la realidad. El poder fundamental de lo real es lo que Zubiri también llama «religación». La religación, aunque universal por afectar a todas las cosas, es en el hombre formalmente patente. Que el hombre esté apoyado en, dominado por, y fundado en, la realidad, es lo que Zubiri afirma cuando dice que el ser humano es la única realidad formal o patentemente religada.

3.3. Sin embargo, la patencia formal de la religación es la de un poder confusamente manifiesto. $\mathrm{O}$, si se quiere, la de una dominancia compactamente aprehendida o, más bien, "co-aprehendida» en la misma aprehensión primordial de realidad — que es el ingrediente de todo acto humano. La ilustración de tal religación es altamente problemática. Y lo es porque el poder le plantea al hombre el problema de su fundamento. Es la cuestión del fundamento del fundamento, es decir, del carácter final de la realidad como fundamento del hombre. La intelección fundamental es la determinación de algún sentido para la realidad-fundamento. Tal es el problema teologal del hombre, como decía Zubiri, o también el problema de Dios: ¿cuál es el sentido de la realidad que nos domina? La realidad es la que se impone al hombre forzándolo a excogitar una orientación intencional. La religación no es un problema en sí misma, sino un hecho. Pero sí que plantea un problema, el de Dios. Debe distinguirse entre el hecho de la religación y el problema de Dios que ella fuerza a resolver en algún sentido $^{64}, \mathrm{o}$, aún mejor, entre la religación al poder de lo real, el problema teologal que este hecho plantea y Dios mismo como posible solución —una entre otras-al problema ${ }^{65}$.

3.4. En concreto, las posibles resoluciones del problema de Dios son de dos tipos. Se trata, por un lado, del esclarecimiento "campal» del sentido de la religación, y por el otro, del sentido «mundanal» o "profundo» tanto de la religación como de sus sentidos campales. Si por uno de sus modos la intelección sentiente del ser humano es dinámica («en hacia», como dice Zubiri), tratándose de la religación hay que admitir que la precisión de su sentido se va realizando al hilo de las intelecciones ulteriores, las que ya no son mera y compacta aprehensión primordial, sino reactualizaciones desdobladas y decisivamente mediadas, o sea, el logos y la razón. Así, aunque el poder dominante de la

64 Cf. un vislumbre de esta distinción en Gracia, D., Voluntad de verdad. Para leer a Zubiri, Labor, Barcelona, 1986, pp. 218-222.

${ }_{65}$ Cf. esta triple distinción ya en Pintor-Ramos, A., «Religación y "prueba” de Dios en Zubiri», en Razón y Fe 218, 1988, pp. 319-336, aquí p. 322. 
realidad sea un hecho previo a todo sentido, es inexorable su determinación en algún sentido. Dicho de otra manera: la realidad, qua poder, se actualiza ulteriormente ante los actos del logos y la razón. La primera de tales reactualizaciones ofrece un sentido que puede orientar a la religación. Es el campo de los sentidos de la religación - sean teístas, agnósticos, ateos (o aun indiferentes). La segunda forma de reactualización de la realidad como poder es la típicamente racional: es la actualidad mundanal que permite esbozar el carácter fundamental de los significados campales de la religación ${ }^{66}$.

\section{El ateísmo EN El LOGOS y EN LA RAZÓN}

Así las cosas, Zubiri piensa que ateísmo, agnosticismo y teísmo (e indiferentismo) son las formas más generales a través de las cuales pretende darse respuesta al problema planteado por la religación. Que el ateísmo, según Zubiri, sea una opción que cabe tomar ante el hecho insuperable de la religación, es algo sobre lo que Zubiri escribió con profusión ya desde sus textos capitales de los años 30 y $40^{67}$. Y es que la religación al poder de lo real está siempre modulada o plasmada de alguna manera. Si la religación es un hecho universal, el teísmo, el ateísmo, el agnosticismo (y el indiferentismo) son, en cambio, representaciones campales de ese mismo hecho. Más aún: son representaciones que tienen sus momentos racionales y que, por lo mismo, constituyen vías de búsqueda de lo que esencialmente late en el fondo del problema de Dios, así como probaciones no teístas del poder de lo real, vale decir, experiencias diversas del dominio de la realidad ${ }^{68}$. Veamos esto más despacio.

${ }_{66}$ Para un desarrollo de estas ideas, véase SolaRI, La raíz de lo sagrado, pp. 182-186. La de Zubiri es una estrategia en modo alguno única; véase por ej. el reciente libro de V. GERHARDT, en cuyo planteamiento aparece también el problema de lo divino, el poder de Dios y la cuestión del sentido que quepa atribuirle: Der Sinn des Sinns. Versuch über das Göttliche, Beck, München, ${ }^{3} 2015$, p. 11.

67 Para un comentario y una reconstrucción de ellos, véase SolARI, La raíz de lo sagrado, pp. 144-146, 148-149, 154-155, 162-163, 168-169 y 187-188. No hay que olvidar que en el inicial artículo «En torno al problema de Dios» la creencia atea no aparece precisamente bajo su mejor luz. Zubiri quizá dudaba entonces de la legitimidad intelectiva de dicha opción. O bien pensando en su propia época, o bien refiriéndose a filósofos como Ortega y Heidegger o aun a cierta etapa pasada de su propia vida, Zubiri habla allí de personas "[...] ejemplares por todos conceptos, pero ante las cuales surge siempre un último reparo: "bueno, ¿y qué?."; existencias magníficas, de espléndida figura, desligadas de todo, errantes y errabundas...»: Zubiri (2004: 452). Podría decirse que Zubiri, cuando diagnostica en la filosofía contemporánea una gigantesca preterición del problema de Dios y cuando contempla tal preterición como un equivalente del ateísmo (véase Zubiri, Naturaleza, Historia, Dios 2004: 453 n.1), lo que en el fondo está haciendo es destacar en tal filosofía contemporánea que su horizonte no es el griego del movimiento ni el cristiano de la nihilidad, sino el actual de la facticidad intramundana, un horizonte al que cabría calificar como metodológicamente ateo o al menos agnóstico. Es algo que habría que estudiar detalladamente.

68 Véase Solari, La raíz de lo sagrado, pp. 349-351. 
4.1. A partir de cierto momento y hasta el final de su vida, Zubiri dejará de considerar al ateísmo como una opción intelectivamente ilegítima. Es algo que ya se aprecia cuando se reconstruye su perfil «lógico», esto es, el logos del ateísmo ${ }^{69}$. Y es que aunque el lenguaje nos haga parecer que el ateísmo es una actitud negativa, se trata en verdad de una afirmación, de una positiva actitud fundamental ${ }^{70}$.

En efecto, puede decirse que para Zubiri el ateísmo sería un «modo de la intención afirmativa». Es en el logos donde Zubiri desarrolla los modos de la intención afirmativa. Cuando no solo se aprehende primordialmente realidad, sino que además se trata de determinar lo que sea eso que se ha aprehendido en un campo real, se está afirmando algo acerca de algo. Es lo que Zubiri denomina «intelección distanciada». Tal distanciamiento se modaliza como ignorancia, como barrunto (que puede ser vislumbre, confusión o sospecha), como duda, como opinión (que puede ser inclinación, probabilidad o convicción), como plausibilidad o bien como certeza. En cada modo de la intelección distanciada, a su vez, se actualiza diferencialmente lo real: puede ser una actualización indeterminada, indicial (= clarescente, borrosa o indicada), ambigua, preponderante (o clinamen, o gravedad, o vencimiento), obvia o bien efectiva ${ }^{71}$.

Para Zubiri, creo, la religión es la plasmación teísta de la religación, y una que puede ser barrunto, duda u opinión. No puede ser, en cambio, pura actualización indeterminada: tal es la ignorancia, «la afirmación suspensiva, vacua, de lo indeterminado en cuanto tal» (y es, dicho sea de paso, el modo intelectivo que especifica a las afirmaciones agnósticas). La religión requiere que la actualización primordial del poder de lo real se actualice positivamente en alguna simple aprehensión de Dios. Tampoco la religión puede ser obviamente plausible ni efectivamente cierta, pues la afirmación religiosa no es unívoca. Puedo decir que tal cosa realiza tal simple aprehensión, pero por el contrario no puedo decir igualmente (ni con obviedad ni con certeza) que el poder de lo real realiza la idea de Dios. Dios no es afirmado cierta ni plausiblemente, ni menos unívocamente, sino que es barruntado, dubitado o bien opinado, pues su (posible) actualización es indicial, ambigua o preponderante. Se puede estar subjetivamente muy seguro al afirmar a Dios, mas no porque su intelección

${ }_{69}$ Sigo aquí algunas ideas ya expuestas en Solari, La raíz de lo sagrado, pp. 261-300 (especialmente 286-287), 336-338 y 343.

70 Zubiri mismo más de alguna vez cayó en la trampa lingüística según la cual la opción creyente atea habría de entenderse negativamente, como si el ateo fuera el que no cree en Dios: ya fue citado al respecto su juicio (bastante tosco) acerca del marxismo como expresa negación de Dios en el curso madrileño de 1968, además puede verse ZuBIRI, Problema teologal, p. 170. Mas, este carácter optativo negativo del ateísmo puede ser corregido recurriendo a la propia noología de Zubiri, porque bajo esta perspectiva toda opción creyente es esencialmente positiva, es una afirmación: el ateo es no el que no cree en Dios sino el que cree que no hay Dios o, si se quiere, el que cree en la facticidad sin dios.

${ }_{71}$ Para esas y otras tesis sobre el logos, véase ZuBIRI, X., Inteligencia y logos, Alianza Editorial, Madrid, 1982. 
distanciada lo actualice ni obvia ni efectivamente ${ }^{72}$. Quizá esto permita asumir la fórmula del Cusano y decir entonces que la intelección religiosa no es pura ignorancia o agnosis, sino una docta ignorancia. Por lo mismo, incluso si fuese verdadera, la afirmación religiosa será siempre y solo una afirmación modalizada entre el barrunto y la convicción, sin alcanzar ni la plausibilidad ni la certeza.

Del ateísmo habría que decir, parejamente, que no es una afirmación ignorante, como tampoco obvia ni cierta. Más bien, la intelección atea es una precisa realización: el barrunto, la convicción o cualquiera de los demás modos intermedios de la afirmación según los cuales el poder de lo real no tiene por fundamento una realidad absolutamente absoluta —como la divina. El ateísmo es una afirmación acerca del poder de lo real, tal como el teísmo y el agnosticismo. No posee el modo de la certeza ni el modo de la plausibilidad. Bien podría decirse que teísmo y ateísmo son contradictorios, y que en cada uno de los modos afirmativos intermedios se contradicen. El ateo afirma que el poder de lo real no realiza la idea de Dios, que esta idea no está realizada en la realidad que nos domina.

En cuanto a la evidencia, Zubiri podría decir que el campo real es un ámbito de exigencia dotado de pluralidad. Tratándose del poder de lo real y sus exigencias campales, la pluralidad campal supone que el poder que religa exige disyuntivamente, en tanto en cuanto exige la realización de simples aprehensiones teístas, o bien de simples aprehensiones no teístas. La realización, pues, llevará a una configuración del poder teísta o no teísta (sea agnóstica o atea o indiferente). La evidencia es en todos estos casos la misma. De ahí que Zubiri diga que hay «innumerables afirmaciones inevidentes, por ejemplo todas las afirmaciones concernientes a una fe tanto religiosa como meramente humana ${ }^{73}$. La representación campal del poder de lo real puede ser religiosa o irreligiosa, puede exigir y evidenciar libremente tanto en uno como en otro sentido. Que sean afirmaciones igualmente inevidentes, según Zubiri, implica más bien que ninguna de ellas tiene una evidencia de la que la otra carecería. $\mathrm{Ni}$ es evidente la fe religiosa, ni lo es la fe no religiosa. Si teísta, ateo y agnóstico están en pie de igualdad, tal igualdad no es sino la exigencia equivalente según la cual es posible una libre determinación del poder religante, sea esta religiosa o irreligiosa.

En el caso del logos, la verdad es una conformación. En general, la conformación es, primero, la coincidencia de lo que es aprehendido con alguna idea libremente construida y postulada. Enseguida, es la coincidencia afirmada de tal idea con lo aprehendido. Si se trata de la conformidad religiosa, habría que decir que es un proceso que va de la autenticidad de la idea de Dios — la conformidad de aquello de que se juzgará con aquello que se juzgará- a su

72 «La certeza, radicalmente considerada, no es un estado mental mío. No se trata de estar seguro sino que se trata de que la cosa aprehendida es así con firmeza total [...] "Estar en lo cierto" no es una seguridad sino el blanco por así decirlo logrado»: ibid., p. 205.

73 Ibid., p. 223. 
realización en la realidad campal —la conformidad de aquello que se juzga con aquello de que se juzga. Nunca tal verdad consistirá en que la realidad confirme plenamente el juicio; es una verdad gradual, o sea, más o menos conforme. La verdad atea, así, es la verdad campal de la idea (con la que coincide el poder de lo real) según la cual no hay Dios y de la afirmación de la misma (ahora coincidente de la idea con el poder). Y esta precaria conformidad vale tanto para el teísmo como para el ateísmo y el agnosticismo (y la indiferencia). Si las vías del teísmo equivalen a las vías no teístas, es porque en el campo no se puede resolver la contienda entre unas y otras. Todas son verdaderas, en tanto en cuanto todas pueden conformarse con el poder de lo real que se manifiesta en la realidad campal. De ahí que este conflicto de las interpretaciones tenga que ser resuelto - y solo pueda ser resuelto— por la razón.

4.2. La legitimidad del ateísmo alcanza por supuesto a la razón y por ende a la creencia y su verdad ${ }^{74}$. Sin la menor duda, para Zubiri son creyentes el ateo, el agnóstico y el teísta. La fe no caracteriza solo a la experiencia religiosa, sino a toda experiencia humana. Todo ser humano consiste en el problema de Dios, tanto el religioso como el ateo, el agnóstico y el indiferente. En todos se manifiesta la voluntad humana de fundamentalidad. Tiene fe el teísta, pero también tiene fe el ateo. Y es que Zubiri concuerda con Ortega; en la existencia humana hay una estructura creyente, y en cada una de las opciones ante la religación y el problema de Dios que ella plantea se está tomando partido, se está llevando a cabo alguna postulación fundamental. La profundización típicamente racional, la marcha hacia el fundamento consiste en construir sentidos mundanales para los sentidos campales que se ofrecen del poder de lo real. En tal empeño el ser humano pone en juego no solo su inteligencia, sino que su ser completo. Por ello es por lo que Ortega aseveraba que las creencias no solo "se tienen», sino que en ellas «se está». Así, toda fe, religiosa o irreligiosa, envuelve una entrega a lo que se cree. De manera que el ateo tiene fe, es decir, cree y somete a probación sus esbozos (acerca de qué es lo que el poder de lo real podría ser). Por lo mismo, su creencia - la fe del ateo- es perfectamente razonable. Si en el agnóstico la voluntad de fundamentalidad consiste en una voluntad de buscar, en el ateo adquiere el modo de una marcha racional, de una voluntad de ser que conduce a la facticidad del poder de lo real y a la autosuficiencia de la vida.

El ateísmo no es solo refutación del teísmo. Es algo positivo, es la verificación de un esbozo ateo. En cambio, no parece racionalmente posible una experiencia de la total falsedad teísta y de la total verdad atea. El ateísmo consiste en la aprobación del esbozo ateo, pero no alcanza nunca a ser refutación plena del esbozo teísta. Si el ateísmo es una actitud razonable, como lo es, es porque está basada en unas experiencias verificadoras de que es plausible conformar la propia existencia sin Dios y de que también es plausible la aproximada

74 Sigo aquí algunas ideas ya expuestas en Solari, La raíz de lo sagrado, pp. 300-336 (especialmente 330-331), 344-346 y 356-357, las cuales remiten precisamente en muchos casos a Inteligencia y razón, Alianza Editorial, Madrid, 1983. 
refutación de una existencia humana divinamente conformada. Lo que no se da es algo así como un pleno y concluyente encuentro (tanto por probación como por refutación) con que en la realidad profunda no hay Dios. El ateo no consigue más que una verificación asintótica de sus esbozos. Por eso la experiencia atea, al igual que la religiosa, no es ni puede ser solamente negativa. El ateísmo es la experiencia de la aprobación del esbozo no teísta, y no mera refutación del teísmo. Podría decírselo así: si es posible la falsedad de la religión o de la irreligión, será porque también es posible la positiva, la verificadora experiencia de aprobación de una y otra.

4.3. Así como el mundo religioso, el de la irreligión también es diverso y plural ${ }^{75}$. Lo que plantea el problema de evaluar a las actitudes irreligiosas desde el punto de vista de la verdad. El logos no puede resolver las pretensiones de verdad de ateos, agnósticos y teístas. Tampoco resuelve, en particular, si alguna forma de ateísmo es más conforme que las demás. Lo que significa que actitudes fundamentales divergentes pueden ser verdaderas, en el sentido de auténticas y conformes desde el nivel intelectivo del logos. Solo la razón y a través de una argumentación no por experiencial menos sofisticada puede arbitrar este conflicto de las interpretaciones. La verdad campal del sentido ateo se vuelve objeto de una búsqueda mundanal. Y si se encuentra un fundamento profundo en el que se cumplan las posibilidades a-teas esbozadas (aunque solo sea de manera itinerante y viable), entonces se verificaría experiencialmente una pretensión de verdad — antes simplemente aprehendida y afirmada.

Pero, como la razón es libre, su verdad es pura aproximación en un proceso interminable, frágil y abierto. La verdad no se agota en el logos, sino que se despliega racionalmente. Y, más aún, cada vez adopta una específica configuración racional, un tipo de lanzamiento intelectivo característico, que a Zubiri le permite hablar de mentalidades racionales —como las artísticas, las científicas o, en lo que aquí interesa, las religiosas o irreligiosas. El logos, que está en condiciones de mostrar la estructura de la razón, no es capaz de resolver cuál de ambas, si la religión o la irreligión, es en profundidad la mentalidad verdadera, o si la experiencia verifica una religión o irreligión entre otras. Semejante resolución está entregada, como diría Kant, al tribunal de la razón. Por ello es que esta, de cara al ateísmo, no tiene otro camino que la experiencia. La experiencia ha de probar los esbozos ateos y elaborar una argumentación racional a su respecto. Como toda probación, la del ateísmo es individual, social e histórica. Y es, a la vez, abierta y «aspectual»: las religiones y los ateísmos sostienen distintas ideas de Dios, tanto así que dentro del mismo ateísmo caben distintos escorzos de la facticidad sin divinidad ${ }^{76}$. En suma: en el campo las actitudes radicales ante el problema de Dios, religiosas e irreligiosas, son equivalentes, y la única posibilidad de resolver esta equivalencia está en la realidad allen-

75 Sigo aquí algunas ideas expuestas en Solari, La raíz de lo sagrado, pp. 336-361.

76 "[...] Esto no es un relativismo. Es un aspectualismo, que es distinto. Veo la realidad fundante de Dios con aspectos distintos»: Zubiri, Hombre y Dios, p. 508. 
de la aprehensión, en la realidad profunda, donde se verificarán o refutarán actitudes y opciones como las ateas. Cabe aquí, sugiere Zubiri, el ensayo más o menos estricto y demostrativo, aunque siempre sea este un asunto de experiencia humana, de la probación de vías más o menos razonables y por lo mismo más o menos aproximadas.

\section{Perspectivas PARA la filosofía de LA RELigión}

La posición de Zubiri, entonces, implica que, después de todo, doctrinas detestables o supersticiosas se pueden hallar no solo en religiones, sabidurías sagradas y teísmos, sino también en agnosticismos y ateísmos, porque, dicho resumidamente por él mismo,

«el ateísmo, como las demás actitudes que vamos a tomar [teístas, agnósticas o indiferentes], son soluciones interpretativas al problema de la verdad real [...] El ateísmo no es una condición primaria del hombre, es una solución. Lo único que es primario es la religación como búsqueda en voluntad de verdad. Cualquier término suyo es una interpretación, verdadera o discutible, eso es una cuestión aparte» ${ }^{77}$.

Sin embargo, la posibilidad misma de distinguir entre formas degradadas y formas justificables de teísmo y ateísmo es algo que habría que examinar detenidamente. Gracias a ello, en fin, podrá al menos indicarse cómo es que estas ideas de Zubiri están en línea con la actual filosofía de la religión, en tanto en cuanto conectan, coincidente o divergentemente, con filosofías fenomenológicas y metafísicas de la religión, con consideraciones políticas de la religión tal como la de la tolerancia y el reconocimiento, y aun con el estatuto teológico del ateísmo al interior del cristianismo.

5.1. Anthony Flew, un conspicuo disputante en la materia, por mucho tiempo desarrolló la idea de que lo más razonable, en una discusión sobre la existencia de Dios, es presumir el ateísmo. En virtud de esta presunción — simplemente legal y, por ende, derrotable-, el ateísmo en sentido meramente negativo («a-tea» sería la postura de todo aquel que no es teísta, en cualquiera de los sentidos que esto pueda tener) no requeriría inicialmente brindar pruebas o razones en su favor, puesto que quien tiene el onus probandi es precisamente el teísta, quien deberá por ello ofrecer tales pruebas o razones de su creencia ${ }^{78}$.

Hemos visto, en cambio, que según Zubiri esta presunción no resulta defendible. Campalmente, porque toda creencia y actitud fundamental está en pie de igualdad y puede ser argumentada, sin que ningún argumento pueda recabar mayor aceptabilidad que los restantes. Mundanalmente, porque si bien cada

$77 \quad$ Ibid., pp. 437-438.

78 Véase Flew, A., "La presunción de ateísmo», en T. Miethe y A. Flew (eds.), ¿Existe Dios? El debate entre un creyente y un ateo, trad. P. Linares, Cátedra, Madrid, pp. 26-36. 
creencia y actitud puede y tiene que brindar sus razones, parece que tanto el teísmo como el ateísmo (y el agnosticismo y la indiferencia) pueden considerarse cuando menos como mentalidades razonables respecto del problema de Dios. Ahora bien, si se apura a Zubiri en este plano de la razón, ha de recordarse que el filósofo vasco — es algo que aquí solo se ha insinuado- admite (y trata de demostrar incluso) una mayor probabilidad en favor del teísmo (y esto, en lo que atañe a la existencia de Dios, por una combinación de argumentos). Zubiri, en este último sentido ya metafísico y peculiarmente abierto a la ciencia, procede muy en la senda de Swinburne, poco en la de Alston y Plantinga, incluso no lejos de la vía que últimamente siguió el propio Flew ${ }^{79}$.

5.2. Por lo mismo, diría Zubiri, no hay directamente percepción de Dios, como la hay de objetos físicos del mundo exterior, pero sí una percepción indirecta de Dios. Parejamente ocurre con el ateo: una experiencia atea será la de una indirecta percepción de la facticidad de la existencia sin Dios, o sea, una afirmación y una experiencia de que la realidad «nos puede» sin ningún sentido absolutamente absoluto.

En ambos casos se trata de que el poder de lo real, oblicuamente percibido en las cosas como su transcendentalidad abierta, desbordante y poderosa, puede ser indirectamente percibido como Dios o bien como pura facticidad. Lo que es tanto como decir que una y otra alternativa son sugerencias alojables campalmente y profundizables mundanal y extramundanalmente. Debe agregarse, sí, que para Zubiri esta percepción de Dios en las cosas es algo enigmáticamente sentido de modos ante todo auditivo, táctil y direccional, pues así es como sentimos in modo obliquo a Dios en tanto que posible fundamento del poder de lo real ${ }^{80}$.

5.3. Ya en el plano moral, la postura de Zubiri incide en discusiones muy contemporáneas. Desde la perspectiva zubiriana, no hay identidad entre religación y moralidad, pues la religación refiere, en comparación con la moral, a un previo momento precisamente fundamental de la realidad humana. A su vez, y como la religión es solo una de las posibles plasmaciones ulteriores de la religación, Zubiri podría agregar que no posee privilegio alguno que alegar en el plano moral. La moralidad es independiente de la opción, religiosa o irreligiosa, de un individuo o una comunidad. Tal independencia se aprecia en la presentación que hace Zubiri de la moralidad en la redacción final de El hombre y Dios, cuando la sitúa volitivamente - distinguiendo entre tendencias y voluntad ${ }^{81}$. También cuando muestra que la voluntad humana, envolviendo la inteligencia

79 Véase Flew, A., Dios existe, trad. F. J. Contreras, Trotta, Madrid, 2012.

80 Véase Solari, La raíz de lo sagrado, pp. 322-325.

81 «[... La aprehensión de esto real, al modificar mis sentimientos, me lanza a responder. ¿De qué modo? Ya no es tender estimúlicamente a una nueva situación animal, sino que es tender a situarse realmente de otra manera en la realidad. Para esto hay que optar. La tendencia y el apetito ceden el paso a la volición. La volición tiene esencialmente un momento de realidad: se quiere un modo de estar en la realidad»: ZuBIRI, Hombre y Dios, p. 55. 
sentiente, abre el orbe novedoso de las posibilidades y la capacitación, o sea, el de la historia, que es toda una dimensión humana y que como las otras dimensiones —individual y social- se modula ecuménicamente en actitudes, prácticas e instituciones religiosas e irreligiosas ${ }^{82}$. Que todo ello permite acreditar fenomenológicamente ese novum que es típicamente humano: la personeidad y su distensión como personalidad ${ }^{83}$. Y que la dimensión moral es entendible como una forma peculiar de causalidad, una irreductible a la causalidad de la metafísica clásica y a la de la ciencia de la naturaleza ${ }^{84}$.

5.4. Enseguida, justo en el plano comunitario o, dicho más estrictamente, de la convivencia humana y su dimensión social, cabría prolongar a Zubiri sugiriendo que la diversidad de las religiones y de las opciones humanas fundamentales - tanto religiosas como irreligiosas - vuelve preferible, moral y políticamente hablando, adoptar virtudes y desarrollar políticas en el preciso sentido de la tolerancia, el respeto y el reconocimiento. Es algo que por supuesto no implica aceptar cualquier opción, sino que exige tamizarla para examinar su justificabilidad en contextos colectivos, el fundamento de su existencia pública. En esto Zubiri es parco, todo hay que decirlo, y muy poco se puede encontrar en su obra comparable a las afirmaciones de Spinoza sobre una república libre y la garantía de la libertad de juzgar, pensar y opinar ${ }^{85}$, o

$82 \quad$ Ibid., pp. 71-81.

83 Ibid., pp. 57-62.

${ }_{84}$ "Y es que la causalidad de la ciencia y de la metafísica clásica son una causalidad entre cosas, entre "lo que" las cosas son. Pero de persona a persona hay una funcionalidad, estricta causalidad por tanto, una causación entre personas, entre "quienes" son las personas. No es una mera aplicación de la causalidad clásica a las personas, sino un tipo de causación irreductible a los de la metafísica clásica y mucho más aún al concepto de ley científica. Es lo que llamo causalidad personal. Por mucho que repugne a la ciencia de la naturaleza, hay, a mi modo de ver, una causalidad entre las personas que no se da en el reino de la naturaleza [...] A este orden de causalidad personal pertenece ante todo lo moral. Que el hombre tenga una dimensión moral es algo que pertenece a su realidad "física". La virtud no es ciertamente algo que el hombre tenga por naturaleza, pero es algo más que un mero valor: es una apropiación real y física de determinadas posibilidades de vida [...] Y justo esto es lo que a mi modo de ver constituye la dimensión moral del hombre, "lo" moral del hombre [...] "La" moral en el sentido de valores, bienes y deberes solo es posible fundada en "lo" moral del hombre. Solo hay bien moral porque el hombre es moral [...] Ahora bien, esto significa que lo moral no se halla en la nuda realidad sustantiva del hombre, esto es, en lo que el hombre individual y específicamente es, sino en su naturaleza personizada [...] Por esto, la llamada causalidad moral es estricta y formalmente causalidad personal. Y lo propio debe decirse, y en grado sumo, de la religación»: ibid., pp. 220-221. Queda abierto aquí si acaso la de Zubiri es una postura compatibilista acerca del libre albedrío, como por ej. la versión de compatibilismo, bastante próxima a la de Frankfurt, que ofrece Carolina SARTORIO en Causation and free will, Oxford University Press, Oxford, 2016, cuyo programa se delinea y concluye en pp. 1-6 y 171-173, y se sintetiza en sus propias palabras en «Resumen de Causation and free will», en Teorema, XXXVII/1, 2018, pp. 51-55.

85 Entre otros lugares, en el capítulo final del Tratado teológico-político: «por tanto, si nadie puede renunciar a su libertad de juzgar y pensar lo que quiera [nemo libertate sua judicandi, \& sentiendi, quae vult, cedere potest], sino que cada cual es dueño de sus pensamientos 
en Kant respecto de la diferencia entre la propensión sectaria y violenta de los credos eclesiásticos y la consciencia de libertad que anima a la fe religiosa en cuanto fe religiosa práctica ${ }^{86}$, o en Hegel acerca de la necesidad de defender a la racionalidad y la autoconciencia frente al ímpetu destructor del fanatismo religioso y político ${ }^{87}$.

5.5. Para terminar, habría que desarrollar con mayores matices la tesis según la cual el ateísmo es elaborable también teológicamente, cosa que el propio

en función del derecho supremo de la naturaleza [sed unusquisque maximo naturae jure dominus suarum cogitationum est], habremos de concluir que en una república no se puede intentar nunca, a no ser con consecuencias muy desafortunadas, que la gente, a pesar de tener ideas diversas y opuestas, hable solo en función de lo ordenado por el soberano, pues ni siquiera los más diestros, por no hablar de la gente corriente, saben callar [...] De los fundamentos de la república [...] se deduce con suma evidencia que su finalidad última no es dominar o refrenar a la gente amedrentándola, o someterla a un derecho ajeno, sino librarla del miedo para que viva con seguridad en la medida de lo posible [...] El verdadero fin de la república es, pues, la libertad [Finis ergo Reipublicae revera libertas est...] Los cismáticos [schismaticos] son más bien aquellos que condenan escritos ajenos e instigan sediciosamente al vulgo arrogante contra sus autores, y no estos autores, quienes la mayoría de las veces se limitan a escribir para los instruidos y recurren solo a la ayuda de la razón. Por otra parte, los verdaderos perturbadores son aquellos que en una república libre quieren eliminar la libertad de juicio, que no es susceptible de ser reprimida [deinde eos revera perturbatores esse, qui in libera Republica libertatem judicii, quae non potest opprimi, tollere tamen volunt]»: SPINozA, B., Tratado teológico-político, trad. J. L. Gil, Laetoli, Navarra, 2014, Cap. 20 [4], p. 304, [6], p. 305, [15], pp. 311-312; cito la versión española con alguna modificación.

86 «Desde el momento mismo en que el credo eclesiástico [Kirchenglaube] empieza a hablar autoritariamente [mit Autorität] para abogar en su favor, sin atender a su propia rectificación mediante la fe religiosa [Religionsglaube], se inicia también el sectarismo [Sectirerei]; pues como la fe religiosa — en cuanto fe racional práctica — no puede perder su influjo sobre el alma humana (influjo que se halla vinculado a la consciencia de libertad [Bewußtsein der Freiheit], mientras que el credo eclesiástico ejerce violencia sobre las conciencias [Gewalt über die Gewissen]) cada cual intenta introducir o quitar algo dentro del credo eclesiástico en provecho de su propia opinión»: El conflicto de las facultades, trad. R. Rodríguez, Alianza Editorial, Madrid, 2003, p. 113 (Ak. VII: 51); cito la versión española con alguna modificación.

87 Hegel es lapidario con el fanatismo religioso y político, que es una manifestación de intolerancia: Principios de la Filosofía del Derecho o Derecho natural y ciencia política, trad. J. L. Vermal, Edhasa, Barcelona, 1988, p. 337. «Pues la devoción, cuando ocupa el lugar del estado, no puede soportar lo determinado y lo aniquila»: ibid., p. 349 (Zusatz de Gans). Por eso cree que «la religión como tal no debe ser pues lo que gobierna» (ibid., p. 349, Zusatz de Gans), y que es preciso «un poder salvador que se haga cargo de los derechos de la razón y de la autoconciencia» frente a «la más dura servidumbre entre las cadenas de la superstición y la degradación del hombre a un nivel inferior al del animal [die härteste Knechtschaft unter den Fesseln des Aberglaubens und die Degradation des Menschen unter das Tier]» (ibid., pp. 335-336). En general, estas épocas de barbarie alcanzan a las iglesias y al estado: en tales tiempos, «toda espiritualidad superior tenía su asiento en la iglesia, [y] el estado no era más que un mundano régimen de violencia, de arbitrariedad y de pasión [ein weltliches Regiment der Gewälttätigkeit, der Willkür und Leidenschaft], y aquella contraposición abstracta se erigía en principio fundamental de la realidad» (1988: 343). Importante es el §5, que incide en la problemática del fanatismo y habla en tono ominoso de su potencia y de la «furia de la destrucción [die Furie des Zerstörens]» (ibid., pp. 68-70). 
Zubiri hace posible cuando defiende una amplia concepción de cristianismo, en cuya virtud el budista - ¿y por qué no el ateo (si es que el budismo en algún sentido puede ser considerado una forma de ateísmo)?-, no a pesar de lo que es sino precisamente porque es lo que es, está inserto en la deiformación y puede acceder a Dios:

«[...] hay una vía distinta, que es la vía de considerar que, por ejemplo, el budista o el brahmán no llegan al Dios cristiano a pesar de ser budistas y brahmanes, sino precisamente en la medida en que son buenos budistas y buenos brahmanes; precisamente por serlo [...] El cuerpo objetivo de las religiones tiene un valor intrínseco de acceso al Dios del cristianismo, no solamente los individuos en razón de su buena fe. Precisamente por ser buen budista puede llegar a la realidad de Cristo ${ }^{88}$.

Esto también puede ejemplificarse con el marxismo, del que Zubiri manifiesta una comprensión más bien superficial y contrastante con aquella otra, precisa y articulada, de Michel Henry, según la cual «Marx est l'un des premiers penseurs chrétiens de l'Occident».

A mi modo de ver, puede decirse que Zubiri no encontraría comprensible la noción de ateísmo religioso, de religión no teísta o sin dios (en el sentido de Dworkin $^{89}$ ), como tampoco la idea inversa de un dios sin religión - sobre todo cuando se habla del cristianismo, es decir, de la fe, como de algo no religioso (así, paradigmáticamente, Barth en Der Römerbrief y Bonhoeffer en Widerstand und Ergebung). Sin embargo, sí podría admitir un cristianismo irreligioso en el sentido de un cristianismo depurado de religiosidad demasiado humana, un cristianismo-de-la-gracia-y-de-la-fe caracterizable, como decía Lutero, por «dejar a Dios ser Dios (Gott Gott sein lassen)» o, en la terminología de Zubiri, para el que Dios es realidad-fundamento y no realidad-objeto, algo toto caelo diferente de un cristianismo idólatra, ideológico, deformado o aun comercial, sustentado en un Dios manejable, a disposición. Esto, por un lado, requeriría comedimiento intelectivo y constante crítica de la razón teológica, para lo cual nunca será en vano asumir terapéuticamente —como el Cusano- la teología negativa y la docta ignorancia ${ }^{90}$. Y por el otro, precisaría de una discusión sutil

88 ZuBIRI, Problema teologal, p. 343; véanse pp. 205, 258, 353, 738.

89 «La actitud religiosa acepta la realidad absoluta e independiente del valor; acepta la verdad objetiva de dos juicios centrales sobre el valor. El primero afirma que la vida humana tiene un significado o importancia objetivos [...] El segundo afirma que lo que llamamos naturaleza - el Universo como un todo y cada una de sus partes- no solo es una cuestión de hecho, sino que es sublime en sí misma: algo con un valor y un asombro intrínsecos»: Dworkin, R., Religión sin dios, trad. V. Altamirano, FCE, México, 2016, p. 18. No cabe duda de que estas ideas de Dworkin podrían interpretarse como semejantes a las de todas las filosofías y teologías para las cuales el núcleo de lo religioso se halla no tanto en lo divino como en lo sagrado: ibid., pp. 23-24 y 35; para un examen crítico de estas tesis, véase SolaRi, La raíz, passim.

90 «[...] Dice el Papa León Magno en el sermón en que alaba a Dios el inefable: "sintamos en nosotros ser bueno que somos vencidos (vincimur). Nadie se acerca más al conocimiento de la verdad que quien entiende que en las cosas divinas, aunque progrese mucho, le queda siempre algo por investigar" [...] Los cazadores filósofos que, desconociendo la esencia de 
de teísmo, ateísmo e idolatría, una que sea sensible a tesis como las de Simone Weil y Juan Luis Segundo (y el mismo Bonhoeffer), según las cuales uno que niega a Dios puede estar más cerca de Dios y tener una idea más pura de él que otro para el cual la religión sea mera fuente de consuelo, de tal modo que la oposición teísmo-ateísmo no sería tan radical como la antítesis fe-idolatría, pues «divide mucho más profundamente a los hombres la imagen que se hacen de Dios que el decidir luego si algo real corresponde o no a esa imagen ${ }^{91}$. Lo cual es cierto si y solo si la idolatría es entendida como degradación o patología de la fe y esta como la alternativa deseable o saludable respecto de aquella, puesto que según un uso menos estipulativo y más lexicográfico la fe sería el rótulo de un complejo de afirmaciones, construcciones, esbozos, razones, mentalidades y experiencias individuales, sociales e históricas, todas ellas creyentes, sean teístas o ateas, y todas admitiendo variedades patológicas y saludables.

Pontificia Universidad Católica de Valparaíso

esolaria@gmail.com

EnZo Solari

[Artículo aprobado para su publicación en enero de 2019]

Dios, se han esforzado en cazar las esencias de las cosas y de convertir en conocida la esencia siempre cognoscible de Dios, llevaron a cabo trabajos inútiles, porque no penetraron en el campo de la docta ignorancia. Solo Platón, que veía algo más que los otros filósofos, dijo que se admiraría si Dios pudiera ser encontrado (inveniri), y que se admiraría más si, una vez encontrado, pudiera ser comunicado (propalari)»: Nicolás de CuSA, La caza de la sabiduría, trad. M. Alvarez, Sígueme, Salamanca, 2014, Cap. 12, p. 83 (De venatione sapientiae, h XII).

${ }_{91}$ Las referencias a ambos se hallan en Fernando Atria, La forma del derecho, Marcial Pons, Barcelona, 2016, p. 435. 